\title{
Drought and Grain Crop Yields over the East European Plain under Influence of Quasibiennial Oscillation of Global Atmospheric Processes
}

\author{
Elena Cherenkova, ${ }^{1}$ Inna Semenova, ${ }^{2}$ Mikhail Bardin, ${ }^{1,3}$ and Alexander N. Zolotokrylin ${ }^{1}$ \\ ${ }^{1}$ Institute of Geography, Russian Academy of Sciences, Staromonetny Per. 29, Moscow 119017, Russia \\ ${ }^{2}$ Odessa State Environmental University, Lvovskaya Street 15, Odessa 65016, Ukraine \\ ${ }^{3}$ Institute of Global Climate and Ecology, Hydromet, Glebovskaya Street 20B, Moscow 107258, Russia \\ Correspondence should be addressed to Elena Cherenkova; lcherenkova@marketresearch.ru
}

Received 23 June 2014; Revised 13 December 2014; Accepted 21 December 2014

Academic Editor: Thomas Reichler

Copyright (C) 2015 Elena Cherenkova et al. This is an open access article distributed under the Creative Commons Attribution License, which permits unrestricted use, distribution, and reproduction in any medium, provided the original work is properly cited.

Monthly precipitation and the 3-month Standardized Precipitation Index (SPI) were used to reveal the patterns of rainfall and severe drought frequency over the East European Plain in the period 1953-2011 in the opposite phases of the quasibiennial oscillation (QBO). Differences of precipitation and severe drought frequency in May and in June in the westward and eastward phases of the QBO phases are explained by circulation variations. The analysis indicates less frequent severe drought events over Ukraine and at the center of the European part of Russia in May in the westward QBO phase due to the intensification of the storm track over the East European Plain. The weather conditions in May and in June in the years of the westward QBO phase were more favorable for the yield. The difference of spring wheat yield in the westward and eastward QBO phase exceeds the same difference of winter wheat yield in the Central Black Earth region and in the south regions. Ukraine and the region to the east of the Sea of Azov are the most vulnerable areas of increased risk of severe drought during the active growing season at the end of the 20th and beginning of the 21 st century.

\section{Introduction}

Drought as a natural phenomenon affects the ecosystems for a long time causing catastrophic damage to the environment and human activities. Formally, a drought is associated with a temporary decrease of the total moisture content due to a rainfall deficiency; it also accompanying the anticyclone activity. However, drought is a complex event and the risk of its occurrence is caused not only by a climatic factors.

The processes initiating drought are studied to reveal the causes of drought, its genesis, and positive/negative feedback mechanisms. The large-scale atmospheric mechanisms related to modes of climate variability and sea surface temperature (SST) anomalies were identified as influencing factors. Among the various forcing, the El-Nino/Southern Oscillation, the North Atlantic Oscillation, North Atlantic sea surface temperature, the quasibiennial oscillation were revealed
[1-3]. However, the quasibiennial oscillation of global atmospheric processes significantly affects the highest-frequency component of the climate system.

It is known that the $\mathrm{QBO}$ affects the atmospheric circulation in the temperate latitudes and its influence propagates to the Earth surface. Regular measurements of the mean zonal wind components are carried by the radiosonde stations of the equatorial belt since 1953. The period of the oscillation is about 28 months [4]. The winds in the eastward phase of the QBO are approximately twice as strong as those in the westward phase. As a component of the global atmospheric circulation the quasiperiodic oscillation of the equatorial zonal wind in the tropical stratosphere (quasibiennial oscillation $(\mathrm{QBO}))$ is the dominant mode of interannual stratospheric variability in the tropics. A mechanism, involving the interaction of internal equatorial gravity waves with the equatorial stratospheric zonal wind [5], was subsequently clarified in 
many studies. However, the mechanism of the QBO influence on the climate is not clarified definitively $[6,7]$.

The signal of the QBO cycle was detected not only in the variability of the stratospheric zonal and meridional wind, temperature, and geopotential height (e.g., $[8,9])$, but also in its influence on the surface meteorological parameters as well, for example, air temperature $[10,11]$, precipitation [12-14], and snow cover [15-17].

In previous studies, the significant $\mathrm{QBO}$ signal was detected in September and October precipitation in the period from 1953 to the 1980s in the region of the British Isles, in the Central European region and in Belarus. Regions of the eastern Ukraine and adjoined regions of Russia had the significant QBO signal in precipitation in May [18]. There are a lot of studies on the detection of the combined impact of the quasibiennial oscillation and the 11-year solar cycle on precipitation patterns and crop yields [18-20]. However, in our research, a similar relationship was not found.

Therefore we limited study choosing for consideration of only the QBO.

Grain crop yield is primarily defined by the level of farming practices (technology), soil type, and climate. The grain belt of the East European Plain is located on a territory with low water resource and unstable moisture conditions. In these circumstances the prediction of the potential effects of changing weather and climate factors on crop yields is very important. The variability of grain yield and the fluctuation of seasonal precipitation on the European part of the former USSR were investigated under influence of quasibiennial oscillation in previous studies [21, 22].

In this study, we extended the period of previous studies, including a period of abrupt climate change (at the end of the 20th century and the beginning of the 21st century). The regional peculiarities of spring-and-summer rainfall precipitation, drought, and grain yield in the south of the East European Plain were revealed under the influence of quasibiennial oscillation of global atmospheric processes. We also investigate circulation differences in the westward and eastward QBO phases, which may be the cause of differences in precipitation and drought.

The purposes of this paper are in investigation of possible influence of the quasibiennial oscillation on the variability of seasonal precipitation, frequency of the spring-summer atmospheric drought, and grain crop yields over the East European Plain and in the research of the cyclone and anticyclone activity in the temperate latitudes in both phases of the QBO.

\section{Data and Methods}

The main grain regions of Ukraine and the European part of the Russian Federation (EPR, the territory of Russia to the west from Ural mountains) located in the drought sensitivity territory of the East European Plain (to the south of $54^{\circ} \mathrm{N}$ ) are in the focus of this study (Figure 1). The territory includes various landscape zones: semidesert, dry and typical steppe, southern and typical forest-steppe, marshy woodlands, and deciduous forests.
Monthly precipitation data of gridded resolution $0.5^{\circ} \times$ $0.5^{\circ}$ were taken from the global monthly dataset CRU TS 3.21 (http://badc.nerc.ac.uk/) to examine the variations of amount of rainfall in both QBO phases. The Standardized Precipitation Index (SPI) data of gridded resolution $1^{\circ}$ were obtained from the global monthly dataset of the National Center for Atmospheric Research (http://rda.ucar.edu/) and were used to analyze atmospheric drought severity. According to Thom's research [23] the gamma distribution fits the observed precipitation time series. The cumulative probability observed precipitation was transformed to the standard normal distribution with a mean of zero to calculate the SPI values in each node of regular grid. The negative values indicate less than median precipitation and dry periods: 0 to -0.99 , mildly drought, -1 to -1.49 , moderate drought, -1.5 to -1.99 , severe drought, and -2 or less, extreme drought. McKee et al. [24] originally calculated the SPI for different time scales from 3 months to 48 months. For this study 3 -month SPI time-series were utilized. Severe droughts of May and June are in the focus of the study as they potentially cause major yield losses. Drought frequency in the each grid cell was calculated as the ratio of the number of years with drought to the total years. Trend of severe drought in every node of the grid was calculated as the linear regression coefficient of a time series of SPI (where the SPI values above -1.5 were replaced by zero).

The QBO phase for the period of 1953-2011 we defined by the $30-\mathrm{hPa}$ equatorial wind direction from April to June (the dataset of Freie Universität Berlin, https://climatedataguide .ucar.edu/). Positive wind speed is associated with the westward QBO phase and negative one with the eastward phase. As a result, the westward phase for the period of 1953-2011 includes 28 years and the eastward phase includes 31 years. The SPI, precipitation, and the crop yield data were categorized according to these phases of the quasibiennial oscillation.

It is well known that precipitation during vegetation period plays the key role to the plant phenology as the most important factor for productivity. Spring grain crops (including spring wheat and spring barley) are sensitive to the atmospheric drought in the south of the East European Plain at the early growing season and they are more drought-resistant in the mature stage $[25,26]$. Agricultural methods in the former Soviet Union have been significantly improved in the 1980 s of the last century. The annual yields of the winter wheat, spring wheat, and spring barley averaged in the regions of Ukraine and Russia according to agricultural statistics (http://agroua.net/statistics/, http://www.gks.ru/) were examined in the study.

The daily NCEP/NCAR reanalysis data of geopotential height of the isobaric level $1000 \mathrm{hPa}$ (spatial resolution $2.5^{\circ}$ ) was used for analysis of the location of the synoptic vortices [27]. The area of the region inside the maximum external closed bounding contour was considered in this study to characterize the synoptic vortex size. The definition of the cyclone/anticyclone center is such that its location should not match the grid cell where the minimum grid value is localized (for details see [28]). The long-term average relative frequency of synoptic eddies in the $5^{\circ} \times 5^{\circ}$ grid node was 


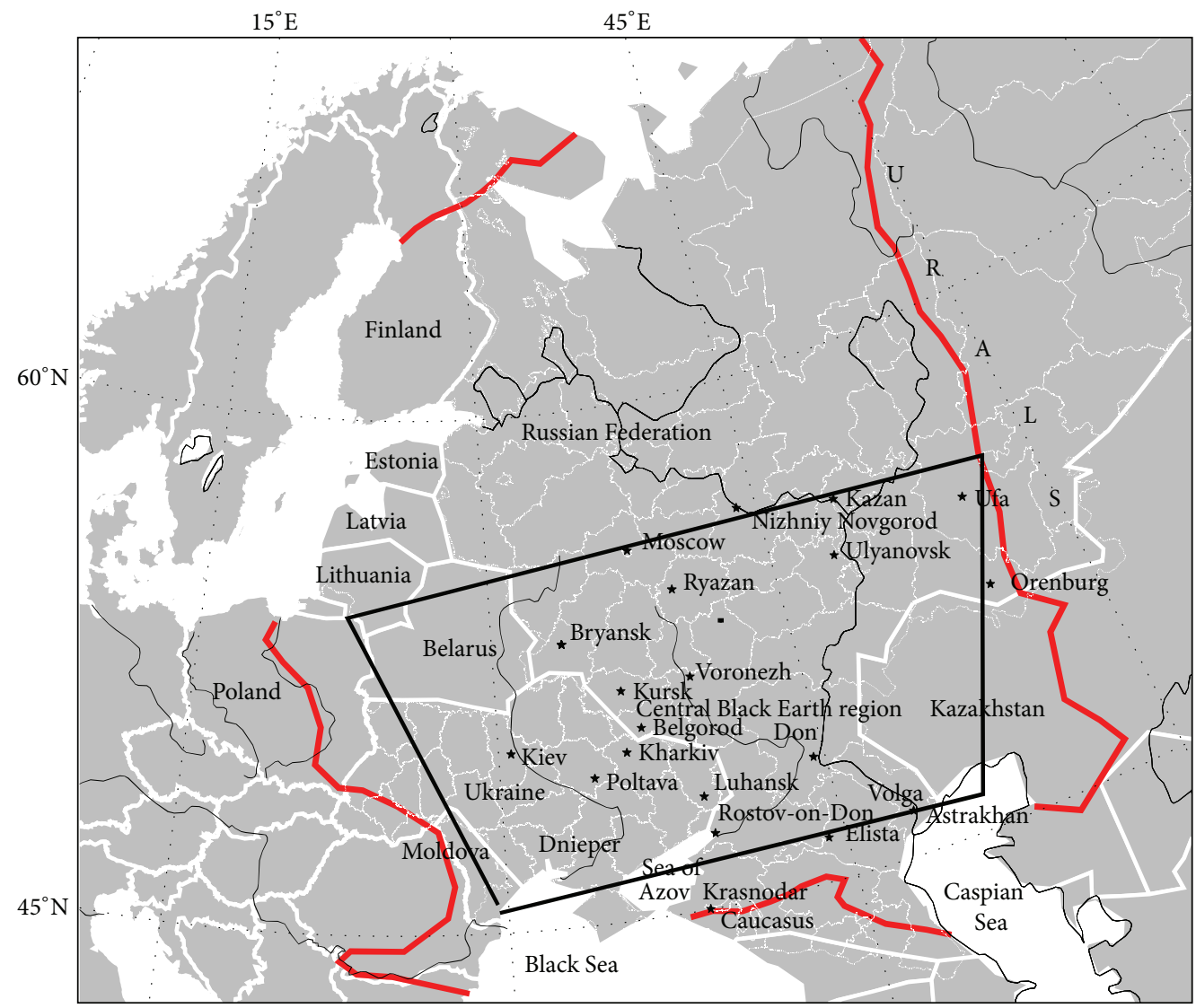

FIGURE 1: The territory of research is limited by black lines. The East European Plain borders are shown by the red line.

determined as a proportion of time when the vortex center is located in the $5^{\circ} \times 5^{\circ}$ cell centered at the node.

In this study we attempt to compare the severe drought frequency patterns, precipitation patterns, and the synoptic eddy patterns in the opposite QBO phases over the East European Plain at the beginning of the growing (vegetation) season for wheat and barley crops and to reveal significant differences. $t$-test for independent samples by groups (at the 0.95 probability level) was applied for determination of statistical significance of precipitation differences and yields differences. Statistical significance of the differences in QBO phases in terms of drought frequency was determined using Fisher's exact test, which is most often applied to dichotomous nominal variables.

\section{Results and Discussion}

The previous study [29] revealed that the drought over the East European Plain occurs under the following global atmospheric circulation patterns.

(i) Arctic air mass formed behind the cold front of the Atlantic cyclone extends into the western and central part of the East European Plain. Area of the high pressure is being established and connects the Arctic anticyclone with the southern anticyclone in the warm season. Extensive drought occurring under these conditions appears more often on the south of the European part of Russia.

(ii) When the arctic air mass invades the Atlantic region or Western Europe, then a branch of the Azores anticyclone is being formed and it is moving eastward up to the south of Western Siberia. Under these conditions extensive drought occurs more often on Ukraine.

(iii) The drought over EPR or Ukraine may arise due to several anticyclones remaining after the destruction of a branch of the Azores anticyclone or an area of high pressure over the east of European Russia.

The mean frequency of atmospheric droughts for 19532011 in the south of the East European Plain in May and in June in both QBO phases according to the SPI data is shown in Figure 2. The highest drought frequency in May and in June in the period 1953-2011 occurred in the westward QBO phase in the Northern Caspian region (up to 6\% cases in May and up to $10 \%$ in June), in the southern Pre-Urals (up to 10\% in May and up to $12 \%$ in June), in the steppes of the Volga region (up to 6\% in May and up to 10\% in June), in the west of Ukraine (up to $8 \%$ in May), and in the east of Ukraine (up to $6 \%$ in May and up to $8 \%$ in June) (Figures 2(a) and 2(b)). The average frequency of severe drought episodes in the south of the East European Plain in the eastward QBO phase was 

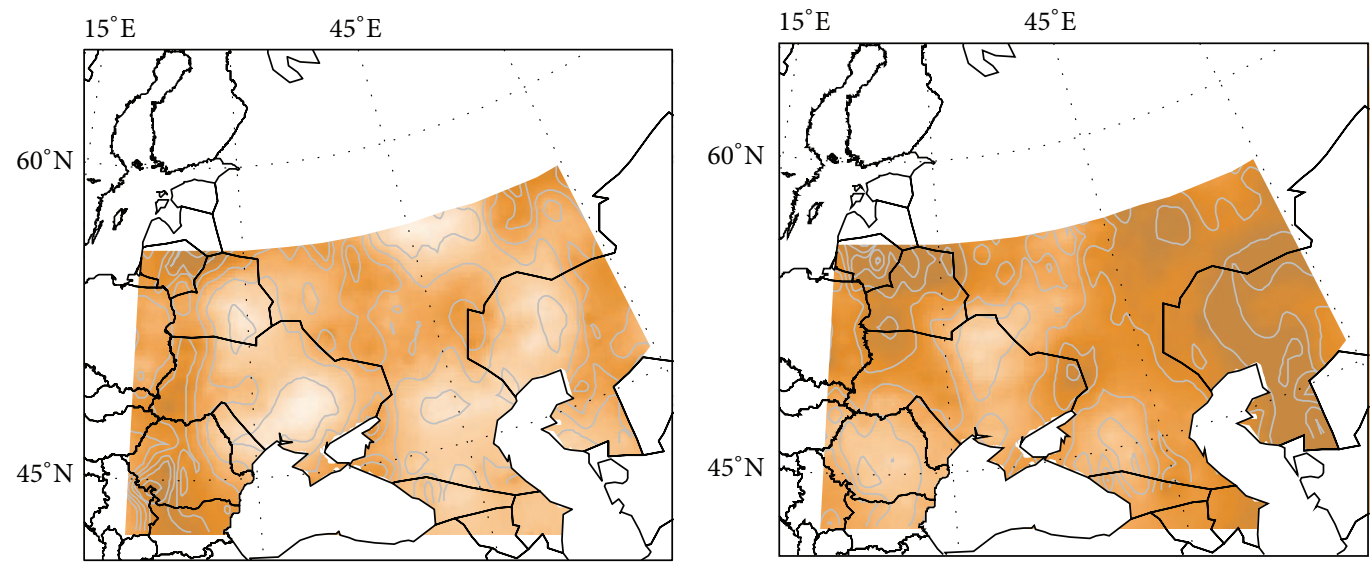

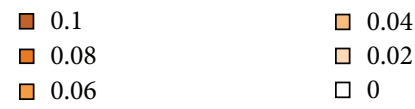

(a)

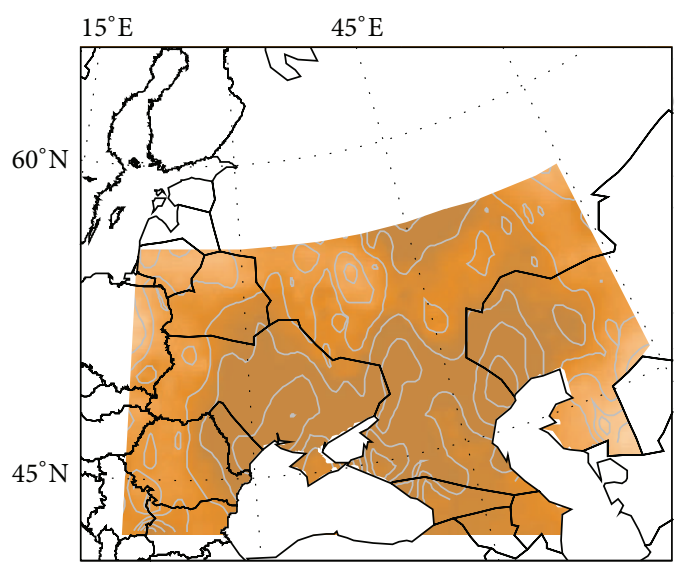
$\square 0.1$
$\square 0.08$
$\square 0.06$
$\square 0.04$
$\square 0.02$
$\square 0$

(c)

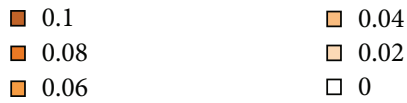

(b)

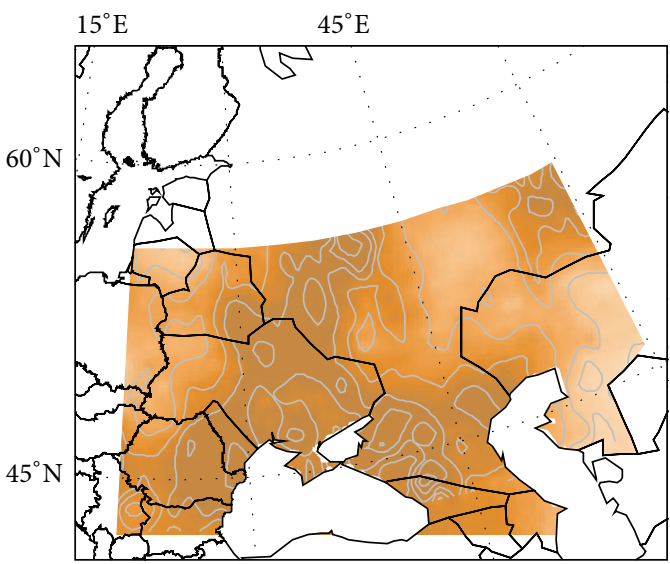

$\begin{array}{ll}\square & 0.1 \\ \square & 0.08 \\ \square & 0.06\end{array}$

$\square 0.04$

$\square 0.02$

$\square 0$

(d)

FIGURE 2: Frequency of severe drought (per/100 years) in the westward QBO phase ((a), (b)) and in the eastward phase ((c)), (d)) in May (on the left) and in June (on the right) in the period 1953-2011 according to the SPI data.

higher than the frequency in the westward phase (Figures 2(c) and $2(\mathrm{~d}))$. The severe drought with highest repeatability in May was observed throughout the south of the East European Plain in the eastward QBO phase: in the center of Ukraine up to $12 \%$, in the region of the Sea of Azov up to $14 \%$, and to the north-west of the Caspian sea up to $14 \%$ (Figure 2(c)). The highest frequency of severe drought in June in the eastward phase observed in the east of Ukraine (up to 10\%) and in the territory between the Black Sea and the Caspian Sea (up to $10 \%$ ) (Figure $2(\mathrm{~d})$ ). The drought frequency in the Volga region and in the southern Pre-Urals during the eastward QBO phase did not exceed 6\% in May (Figure 2(c)) and 3\% in June (Figure 2(d)).

As shown in Figures 3(a) and 3(b), higher precipitation in Ukraine and in the south of the European part of Russia was observed in May and June in the westward QBO phase. The significant westward/eastward phase differences in precipitation in May are localized in central Ukraine (differences from $27 \%$ to $59 \%$ ), in the west of Central Black Earth region of Russia (differences from $27 \%$ to $37 \%$ ) and in the lower Don basin (from $33 \%$ to 58\%). Differences in the amount of rainfall in June in both QBO phases are significant only in small areas to the north of the Caspian Sea. Our results are consistent with the previous studies [18].

Figure 3(c) demonstrates that the lower frequency of severe drought in May in the westward QBO phase as compared to the eastward one was observed in the south of the East European Plain (with the exception of small areas). The significant differences in the frequency of severe drought in May were identified in central Ukraine (differences from 13 

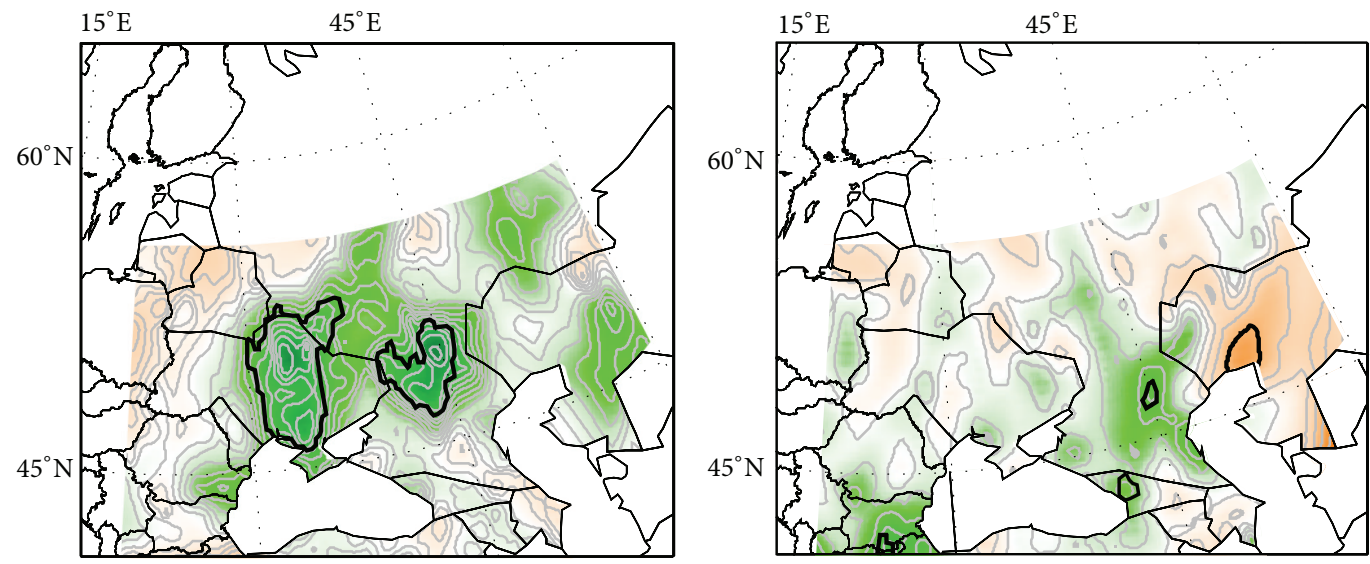

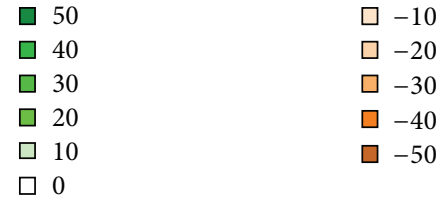

(a)

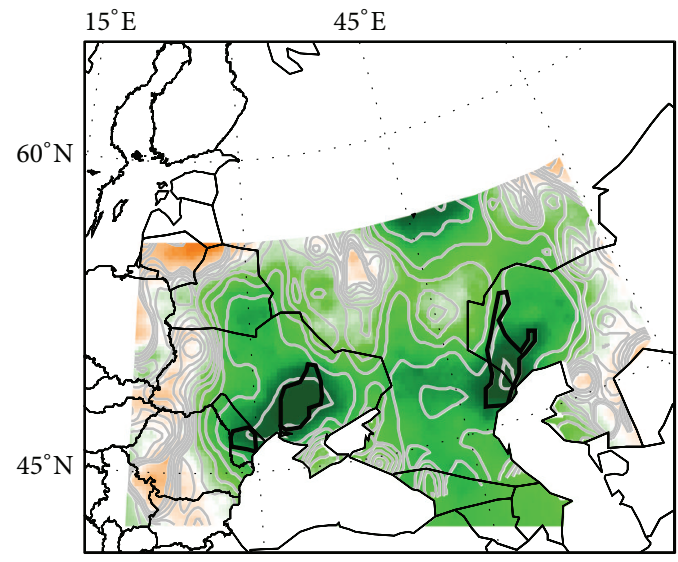

0.12

$\square 0.1$

ㅁ 0.08

ㅁ 0.06

0.04

0.02

ㅁ 0
-0.02

ㅁ -0.04

ㅁ -0.06

ㅁ -0.08

ㅁ -0.1

ㅁ -0.12

(c)

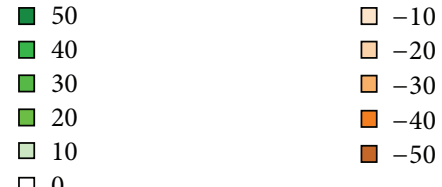

(b)

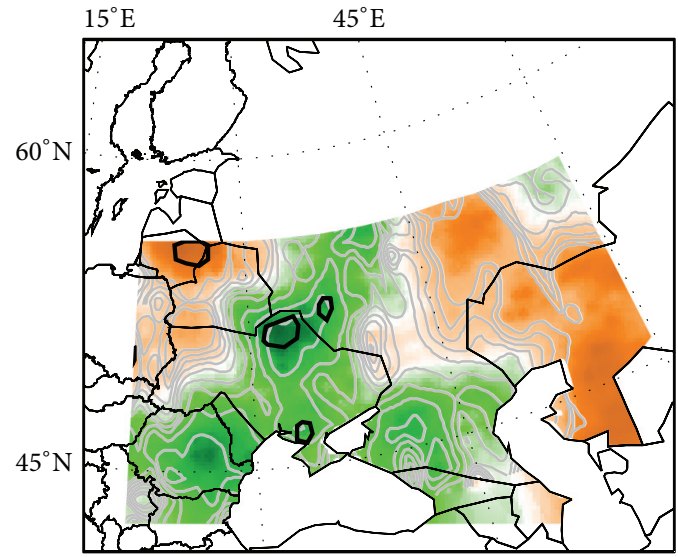

$\begin{array}{ll}\text { ㅁ } & 0.12 \\ \square & 0.1 \\ \square & 0.08 \\ \square & 0.06 \\ \square & 0.04 \\ \square & 0.02 \\ \square & 0\end{array}$

ㅁ -0.02

ㅁ -0.04

ㅁ -0.06

ㅁ -0.08

ㅁ -0.1

-0.12

(d)

FIGURE 3: Difference in precipitation (\%) ((a), (b)) and severe drought frequency (per/100 years) ((c), (d)) over the East European Plain in the westward QBO phase as compared to the eastward phase in May (on the left) and in June (on the right) in the period 1953-2011. Significant differences are shown inside the black contours.

to 16 severe drought per 100 years) and to the north of the Caspian Sea (differences from 13 to 20 severe drought per 100 years). Analysis has shown that the same frequency in June is lower in the north of Ukraine (differences from 9 to 12 severe drought per 100 years), in the west of Central Black Earth region (differences to 9 severe drought per 100 years), and in the Rostov Oblast and in the Krasnodar Krai (differences to 9 severe drought per 100 years), but it is higher in the Volga region (differences to 11 drought in 100 years). However, only small areas of significant differences in the west of Central Black Earth region and in the north of Ukraine were detected.

Despite the fact that areas of significant differences are relatively compact, one should note that the spatial coherence of the difference sign over vast regions strongly indicates the influence of the QBO phase on both precipitation and drought. 

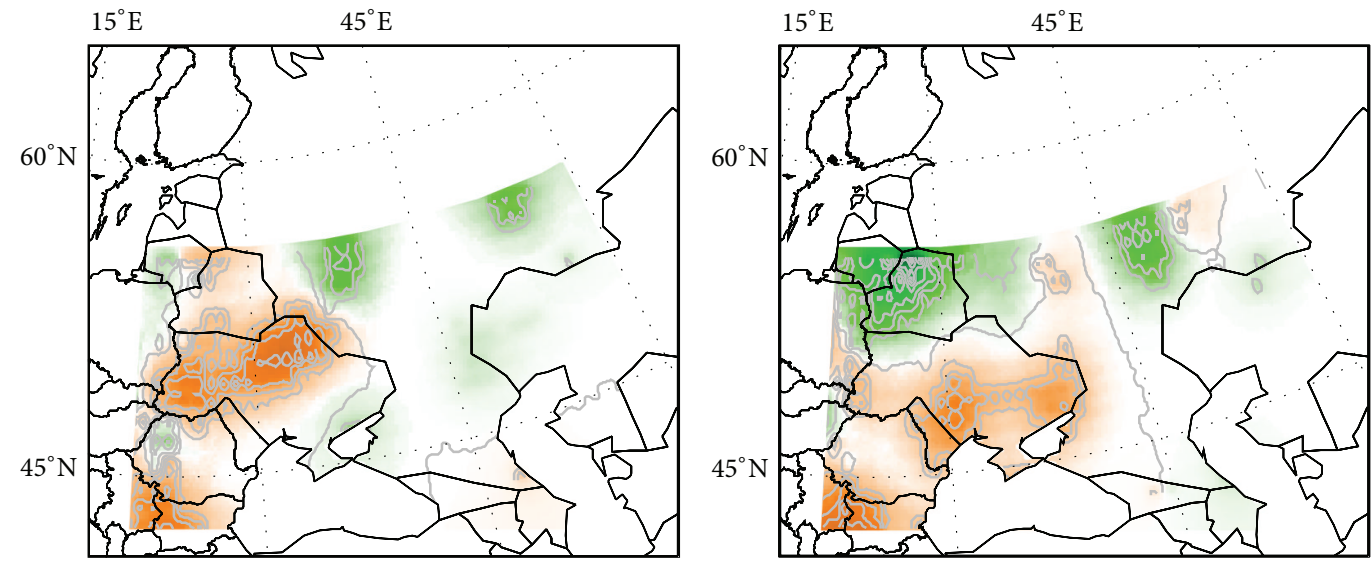

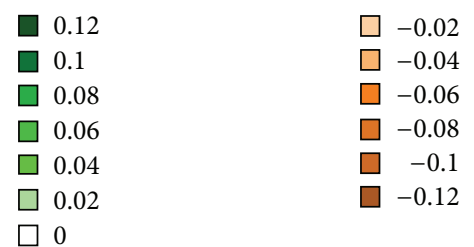

(a)
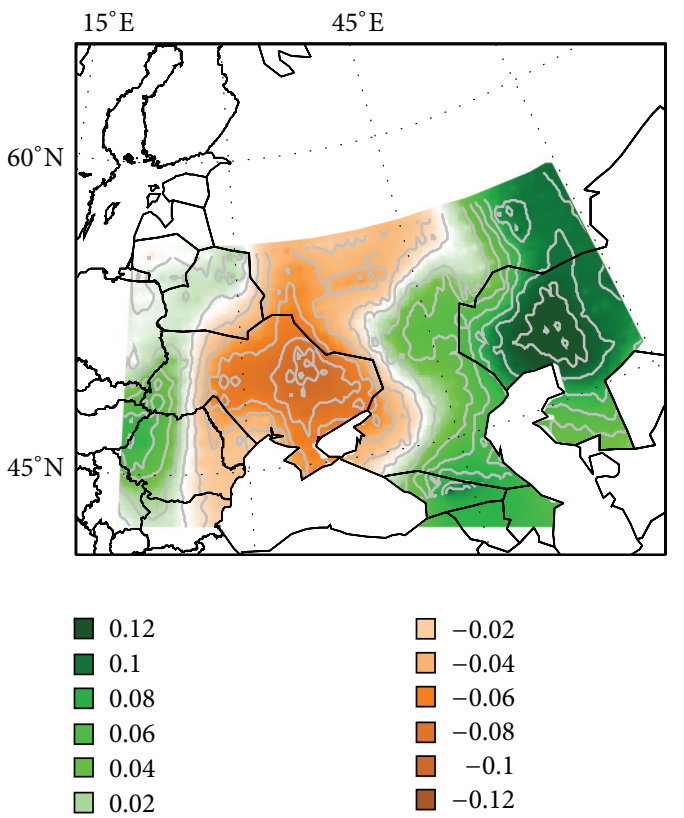

(c)

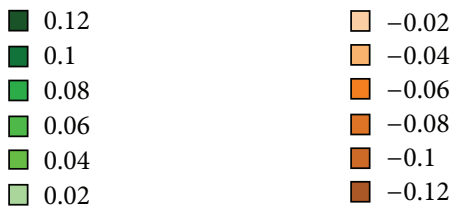

(b)

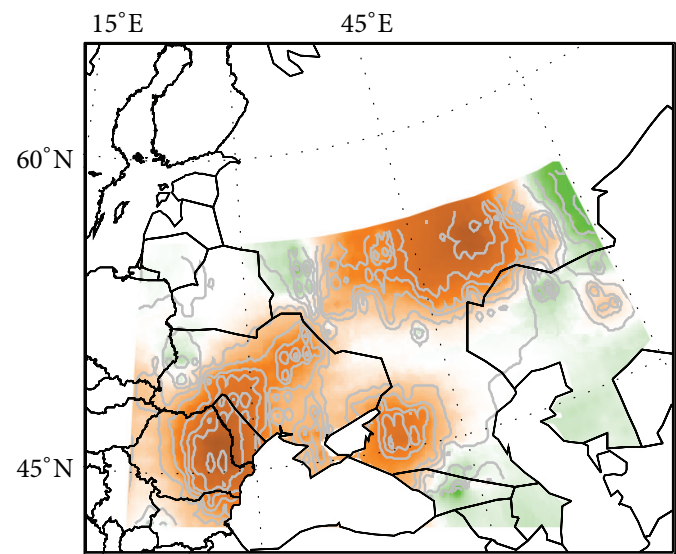

$\square 0.12$
$\square 0.1$
$\square 0.08$
$\square 0.06$
$\square 0.04$
$\square 0.02$
$\square 0$

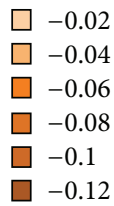

$\square-0.04$

$-0.06$

$-0.1$

(d)

FIGURE 4: Linear regression coefficient of severe drought in the westward QBO phase ((a), (b)) and in the eastward QBO phase ((c), (d)) in May (left) and June (right) during the period 1991-2011 according to SPI.

Multidirectional coefficients of the linear trend of severe drought in the East European plain in both QBO phases were identified during the period of active climate change of 1991-2011 (Figures 4(a), 4(b), 4(c), and 4(d)). The highest rates of drought count increase were detected in the eastward QBO phase: the largest negative trends in May were revealed in Ukraine (excluding the western regions) (Figure 4(c)), and the similar trends in June were identified in the center of Ukraine, to the east of the Azov Sea, and in the Volga region (Figure 4(d)). Negative trends in the westward QBO phase were revealed only in May in the north of Ukraine (Figure 4(a)).

Increase of spring wheat yield in the European part of Russia averaged for years of the western QBO phase is consistent with the increase in precipitation and reduction of severe drought frequency over the East European Plain observed 


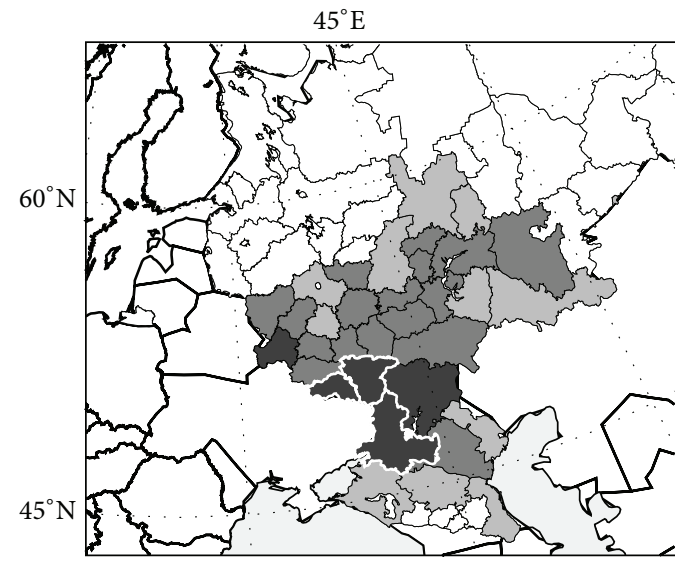

(a)

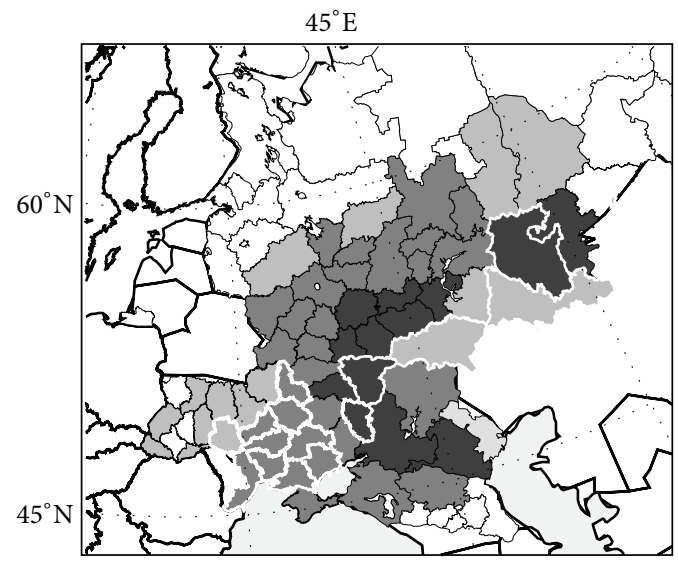

(c)

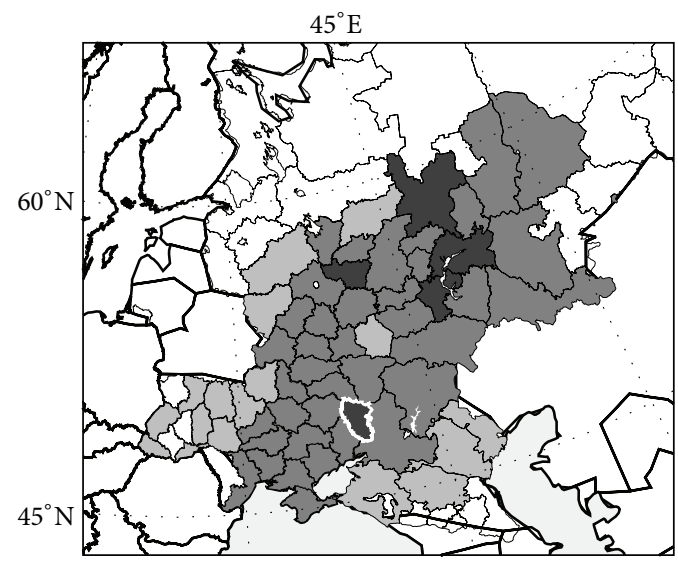

(b)

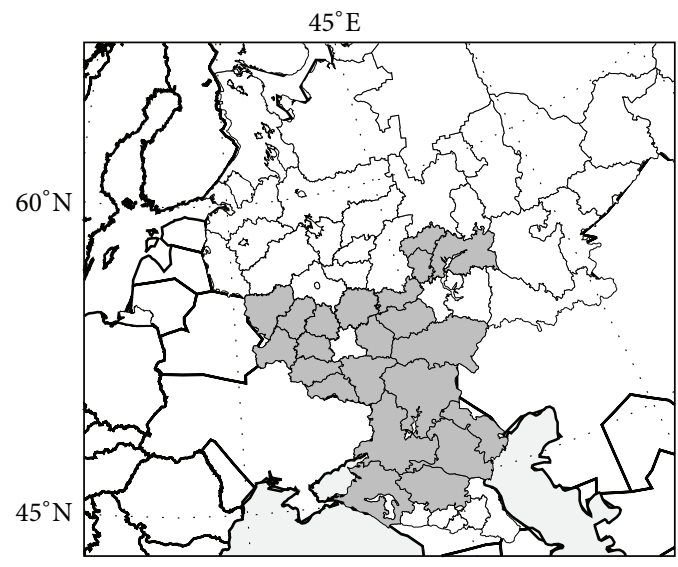

(d)

FIGURE 5: The difference of crop yield in the East European Plain in the westward QBO phase as compared to the eastward phase: (a) spring wheat yield and (b) winter wheat yield in the period 1953-2011 and (c) spring barley yield in the period 1958-2011. The positive difference exceeding $20 \%$ is shown by dark gray color, $10-20 \%$ gray color, and less than $10 \%$ light gray color. White contour shows significant difference. The positive differences of the spring wheat yield and the winter wheat yield in the westward QBO phase as compared with eastward phase are shaded (d).

in the same period. The largest increase of the yield of spring wheat was detected in the western regions of the EPR (35.5\% in the Bryansk Oblast, 25.9\% in the Belgorod Oblast, 26.8\% in the Rostov Oblast, 23.9\% in the Volgograd Oblast, and $23.3 \%$ in the Voronezh Oblast) declining on the direction to the north-east (Figure 5(a)). The patterns of winter wheat yield in both QBO phase are less consistent with patterns in rainfall and severe drought compared to spring wheat yield (Figures 3 and 5(b)). This effect can be explained by the fact that important weather conditions of vegetation for growing season in the autumn and winter conditions for the winter wheat crop have not been analyzed. The largest increase of the winter wheat yield averaged on the westward QBO phase years compared to the same in the eastward phase has been revealed in the Ulyanovsk Oblast (21.3\%), in the Republic of Tatarstan (21.8\%) and in the Luhansk Oblast (21.4\%). Significant difference in the winter wheat yield in both phases was detected only in Luhansk Oblast. The results are consistent with previous studies of variability of winter and spring wheat yields in the QBO phases [21,22]. Note that the sustainability of the $\mathrm{QBO}$ signal in various regions was determined by the studied period.

The results of the comparison of areas of increased precipitation and spring barley yield and the areas of the decrease of the drought frequency in the westward QBO phase in the period 1958-2011 are consistent (Figures 3 and 5(c)). The major increase of the spring barley yield in the westward QBO phase was noticed in the Republic of Bashkortostan (30\%), in the Rostov Oblast (28.3\%), in the Ryazan Oblast (26.8\%), in the Republic of Kalmykia (26.9\%), and in the Luhansk Oblast (27.6\%) (Figure 5(c)).

The yield of both wheat types in the European part of Russia in the westward QBO phase exceeds the same yield in the eastward phase in the Central Black Earth region (by $3-10 \%$ ) and in the south regions (by $5-12 \%$ ) in the period 1953-2011 (Figure 5(d)). More difference for spring wheat was 


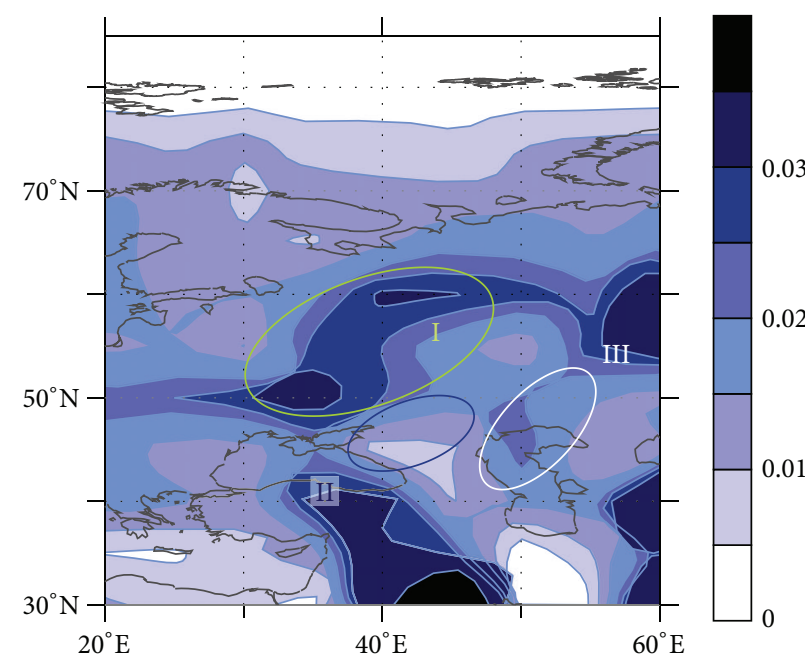

(a)

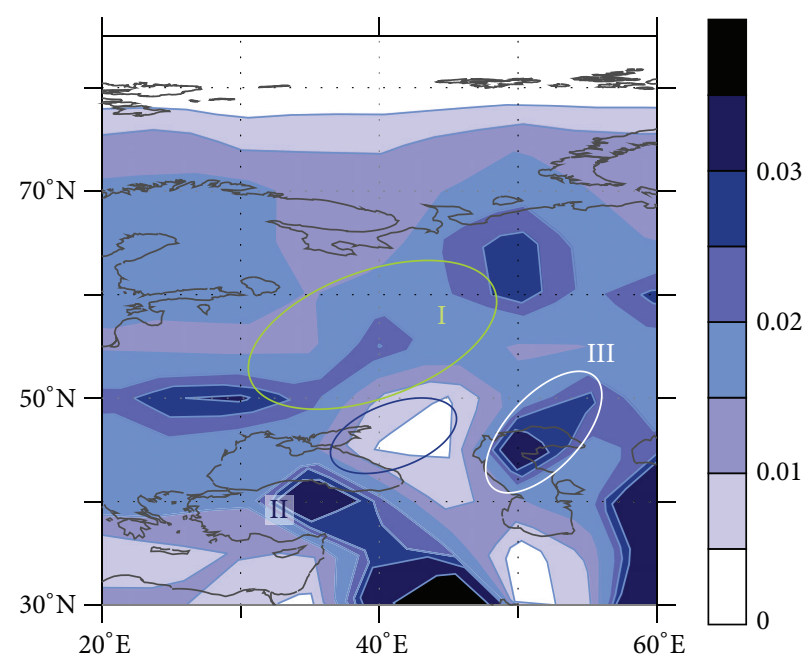

(b)

FIGURE 6: Relative frequency of the cyclones occurrence (the percentage of time in the grid cell $5^{\circ}$ of the cyclone center) in May in the westward (a) and eastward (b) QBO phase. Denoted areas are described in text.

associated with its sensitivity to the rainfall deficiency and drought during the active growing season in May at the East European Plain.

The increased humidification in the south of the East European Plain in May in the period 1953-2011 in the westward QBO phase can be explained by the difference in the cyclonic activity in the opposite QBO phases (Figure 6). The principal storm track in the region is localized zonally about $50^{\circ} \mathrm{N}$ over Ukraine; it is displaced north-westward at about $35^{\circ} \mathrm{E}$ in May in both QBO phases. However, the storm track intensified strongly in the westward QBO phase and the highest cyclone frequency shifted from the west to the east of Ukraine to the Poltava-Kharkiv region (area I in the Figure 6(a)). Furthermore, the intensification and expansion of the storm track resulted in the increase of density of the cyclone centers in the south of EPR in the Rostov Oblast and in the Krasnodar Krai (area II in the Figure 6(a)). Rainfall is associated with the passage of a cyclone; it caused the increased humidification in the south of the East European Russia in the westward QBO phase. Note that significant difference in the frequency of the cyclones occurrences in June was not found (not shown).

We analyzed variations of the atmospheric circulation using the average characteristics of anticyclone activity («composites») to explain the increased and decreased humidification. The decrease of moisture content in the Voronezh Oblast, Rostov Oblast, Volgograd Oblast, Astrakhan Oblast, and Republic of Kalmykia in May and June in the westward QBO phase was observed. The increased moisture content occurred in the North Caucasus and in the southern Pre-Urals. The reduced aridity in May is associated with lower anticyclone frequency (area M1 in the Figure 7(a)) along with higher cyclone recurrence (Figure 6(a)). At the same time, higher frequency of the anticyclone in the westward phase was observed in the North Caucasus (area M2 in the Figure 7(a)).
The anticyclone frequency in the southern Pre-Urals in May in both QBO phases is approximately the same, but sizes of anticyclones are greater there and therefore larger areas are subjected conditions conducive to the drought here. In addition, larger and less mobile anticyclones effectively block cyclones to the north of the Caspian Sea (area III in the Figure 6(b)).

As shown in the Figure 8, the similar patterns of anticyclone activity in June in the opposite phases are observed (in the westward phase: reduced frequency of the anticyclones in the J1 area (Figure 8(a)); increased frequency of the anticyclones in the J2 area (Figure 8(a)); the larger cyclones in J3 area (Figure 8(c))). Maximum of the anticyclone area in the eastward phase over the east of Ukraine hardly leads to additional increase of aridity in the south of the East European Plain, due to the low frequency of the anticyclone occurrence (Figures $8(\mathrm{~b})$ and $8(\mathrm{~d})$ ).

More precipitation and less frequency of the severe atmospheric drought over the East European Plain on average in the years of the westward QBO phase as compared to the eastward phase during the period 1953-2011 resulted in more yields of the spring wheat. The observed effects are explained by circulation differences in the QBO phases. Therefore the priority of the use of spring wheat in the Central Black Earth region and in the steppes of the European part of Russia in the westward phase can reduce agricultural risks. In this case, the quasibiennial oscillation may be used as one of the reliable predictors. However, this topic requires further study including the other drivers of the influence on crop yield.

\section{Conclusion}

Significant QBO signal in precipitation, atmospheric drought, and crop yield in May-June in the south of the East European plain was detected in the period of 1953-2011, including the period of active climate change. Largest areas 


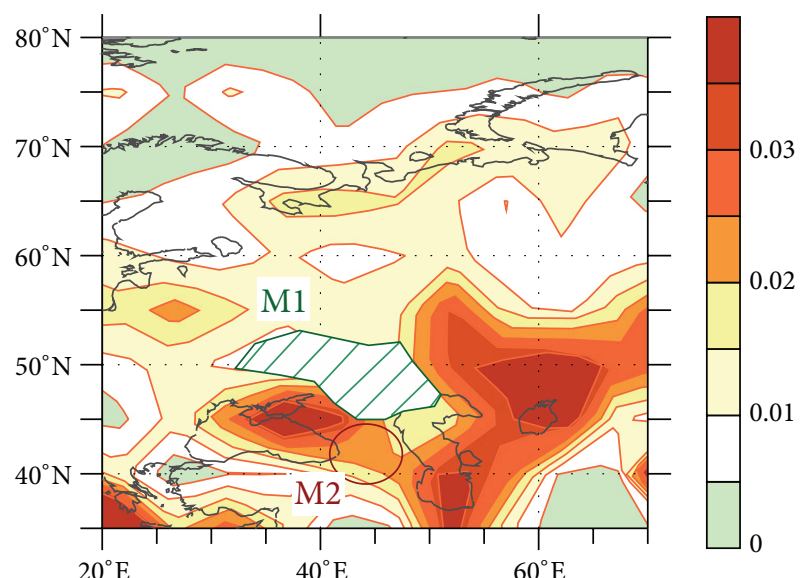

(a)

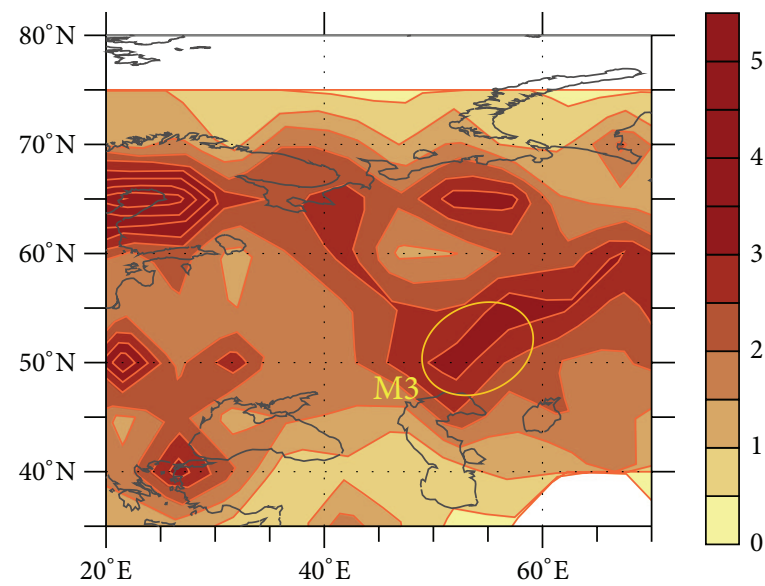

(c)

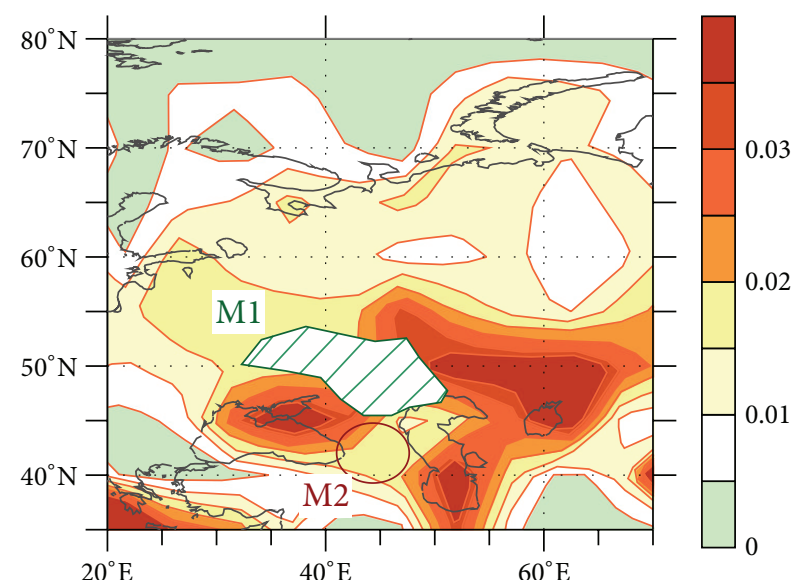

(b)

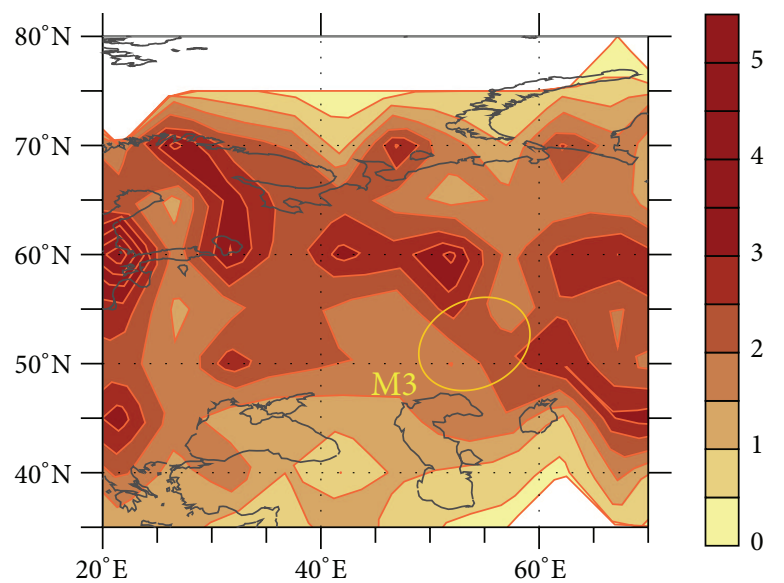

(d)

Figure 7: Relative frequency ((a) and (b)) and average area $\left(10^{6} \mathrm{~km}^{2}\right)((\mathrm{c})$ and (d)) of the anticyclones in May in the westward (a) and (c) and eastward (b) and (d) QBO phases.

of the significant differences of precipitation and drought frequency in the QBO phases were identified in May. More rainfall and less severe drought frequency in May and June (excluding the area north of the Caspian Sea) were observed in the south of the East European Plain in westward QBO phase compared to eastward $\mathrm{QBO}$ phase. The significant westward/eastward phase differences in precipitation in May were localized in central Ukraine, in the west of Central Black Earth region of Russia, and in the lower Don basin. Less uniform patterns of precipitation in the south the East European Plain were revealed in June. The significant differences in the frequency of severe drought in May were identified in central Ukraine and to the north of the Caspian Sea. Analysis has shown that the same frequency in June is lower in the north of Ukraine, in the west of Central Black Earth region, in the Rostov Oblast, and in the Krasnodar Krai, but it is higher in the Volga region.

At the same time, trends of severe drought in the East European Plain in both QBO phases during the period of active climate change of 1991-2011 were spatially nonuniform. The largest trends of increased drought in May and in June in
Ukraine (mostly in the central regions) and in the region to the east of the Sea of Azov were revealed in the eastward QBO phase. Trends of the same sign in the westward QBO phase were detected only in Ukraine. Thus, Ukraine and the region to the east of the Sea of Azov were identified as the most vulnerable regions of increased risk of severe drought during the active growing season at the end of the 20th-beginning of the 21st century in the south of the East European Plain.

Differences of precipitation and severe drought frequency in May and in June in the period of 1953-2011 in the QBO phases are explained by differences in circulation patterns in the westward and eastward phases of the QBO. The intensification of the storm track over the East European Plain in May in the westward QBO phase results in the decrease of humidification in Ukraine and at the center of the European part of Russia. Along with that, the increased aridity in the Volga region and the southern Pre-Urals in May and in June is associated with the higher frequency and/or more powerful extensive anticyclones.

The weather conditions in May and in June in the years of the westward QBO phase in the period of 1953-2011 were 


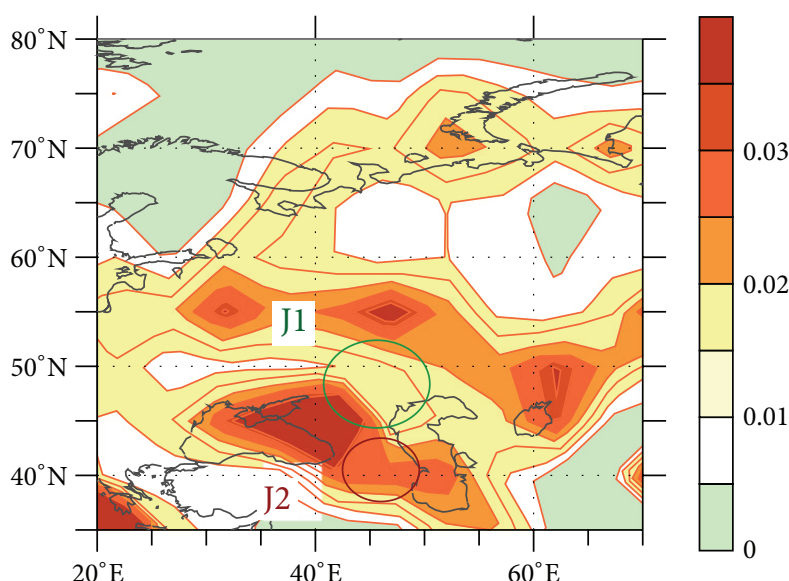

(a)

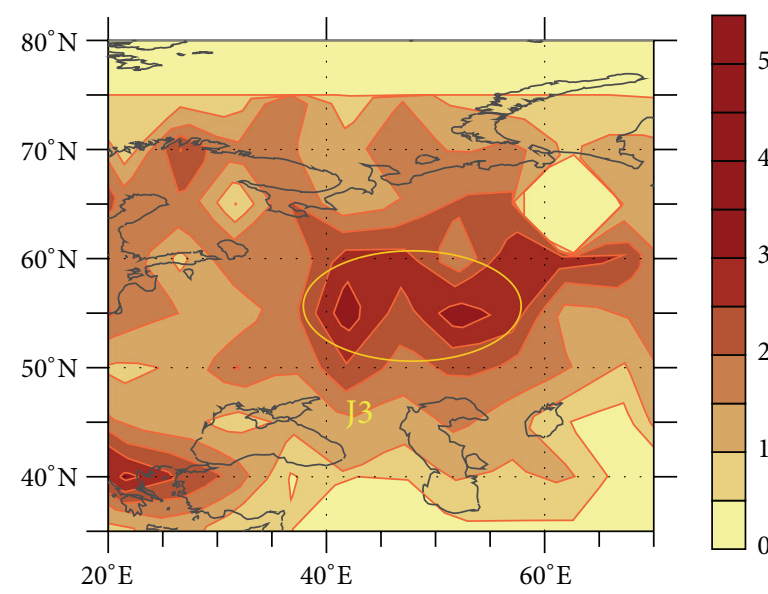

(c)

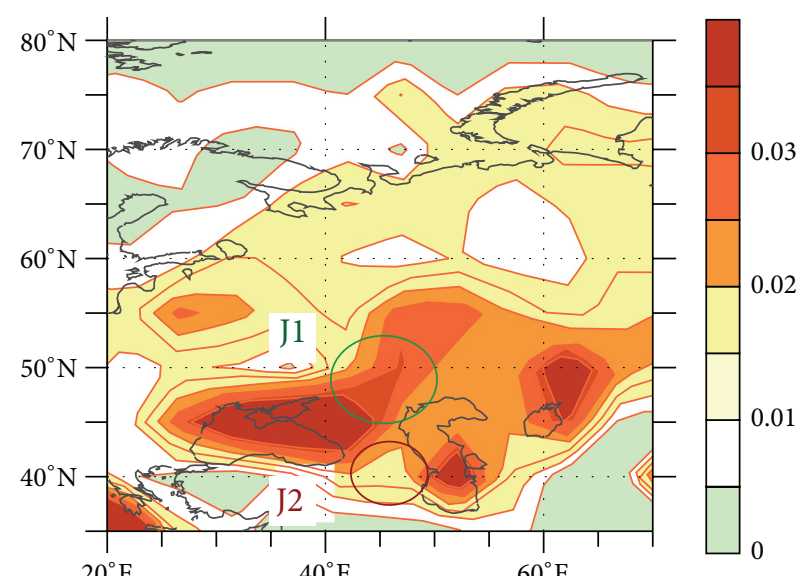

(b)

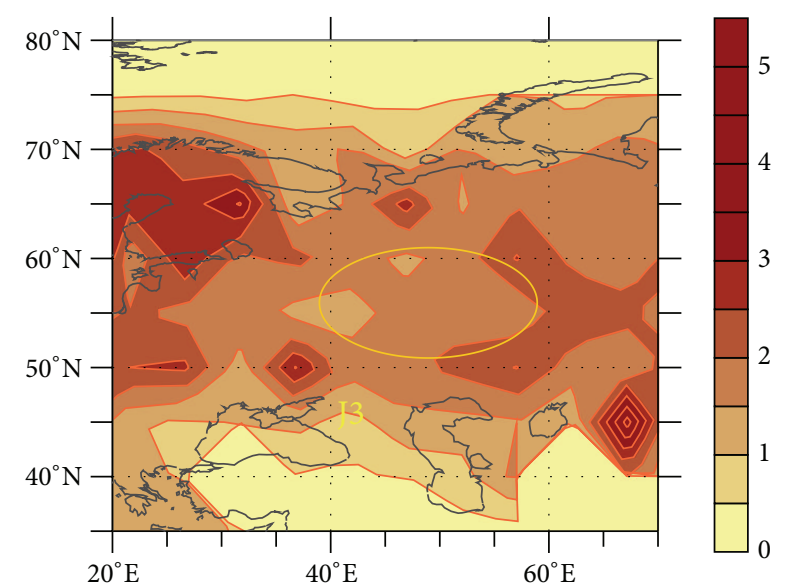

(d)

Figure 8: Similar to Figure 7, but in June.

more favorable for the yield. The average yield of winter wheat, spring wheat and spring barley in the south the East European plain in westward QBO phase during the period 1953-2011 exceeded the same yield in the eastward phase. The difference of spring wheat yield in the European part of Russia in the westward QBO phase exceeds the same difference in the eastward phase in the Central Black Earth region (by 3$10 \%$ ) and in the south regions (by 5-12\%) in the period 19532011. Higher difference for spring wheat was associated with its sensitivity to the rainfall deficiency and drought during the active growing season at the East European Plain.

\section{Conflict of Interests}

The authors declare that there is no conflict of interests regarding the publication of this paper.

\section{Acknowledgment}

The study was conducted at the financial support of the program accepted by Russian Academy of Sciences "Desertification of Dry Lands in the South of Russia in the Context with Climate Changes."

\section{References}

[1] C. K. Folland, J. Hannaford, J. P. Bloomfield et al., "Multi-annual droughts in the English Lowlands: a review of their characteristics and climate drivers in the winter half year," Hydrology and Earth System Sciences Discussions, vol. 11, no. 11, pp. 1293312985, 2014.

[2] S. D. Schubert, M. J. Suarez, P. J. Pegion, R. D. Koster, and J. T. Bacmeister, "Causes of long-term drought in the U.S. Great Plains," Journal of Climate, vol. 17, no. 3, pp. 485-503, 2004.

[3] R. Seager, Y. Kushnir, C. Herweijer, N. Naik, and J. Velez, "Modeling of tropical forcing of persistent droughts and pluvials over Western North America: 1856-2000," Journal of Climate, vol. 18, no. 19, pp. 4065-4088, 2005.

[4] M. P. Baldwin, L. J. Gray, T. J. Dunkerton et al., "The quasibiennial oscillation," Reviews of Geophysics, vol. 39, no. 2, pp. 179-229, 2001.

[5] R. S. Lindzen and J. R. Holton, "A theory of the quasi-biennial oscillation," Journal of the Atmospheric Sciences, vol. 25, no. 6, pp. 1095-1107, 1968.

[6] J. A. Anstey and T. G. Shepherd, "High-latitude influence of the quasi-biennial oscillation," Quarterly Journal of the Royal Meteorological Society, vol. 140, no. 678, pp. 1-21, 2014. 
[7] P. A. G. Watson and L. J. Gray, "How does the quasi-biennial oscillation affect the stratospheric polar vortex?" Journal of the Atmospheric Sciences, vol. 71, no. 1, pp. 391-409, 2014.

[8] J. K. Angell, J. Korshover, and G. F. Cotton, "Quasi-biennial variations in the 'centers of activity"' Monthly Weather Review, vol. 97, no. 12, pp. 867-872, 1969.

[9] A. S. Huesmann and M. H. Hitchman, "The stratospheric quasibiennial oscillation in the NCEP reanalyses: climatological structures," Journal of Geophysical Research D: Atmospheres, vol. 106, no. 11, pp. 11859-11874, 2001.

[10] R. Bradzil, K. Kozuchowski, K. Marciniak, and T. N. Tam, "Variation of annual air temperatures in Europe in the period of 1881-1980," in Climatic Changes and Their Importance for the National Economy, pp. 115-130, Vysoká Škola Zemědělská, Brno, Czech Republic, 1987.

[11] H. E. Landsberg, J. M. Mitchell, H. L. Crutcher, and F. T. Quinlan, "Surface signs of the biennial atmospheric pulse," Monthly Weather Review, vol. 91, no. 10, pp. 549-556, 1963.

[12] R. Brázdil, "Fluctuation of atmospheric precipitation in Europe," GeoJournal, vol. 27, no. 3, pp. 275-291, 1992.

[13] K. V. Konyaev and A. N. Zolotokrylin, "O dvukhletnikh kolebaniyakh osadkov," Materialy meteorol. Issled, no. 14, pp. 103-113, 1988 (Russian).

[14] K. M. Lau and P. J. Sheu, "Annual cycle, quasi-biennial oscillation, and southern oscillation in global precipitation," Journal of Geophysical Research, vol. 93, no. 9, pp. 10975-10988, 1988.

[15] R. J. Allen and C. S. Zender, "The role of eastern Siberian snow and soil moisture anomalies in quasi-biennial persistence of the Arctic and North Atlantic Oscillations," Journal of Geophysical Research D: Atmospheres, vol. 116, no. 16, Article ID D16125, 2011.

[16] P. Dobrovolny, "Variation of the snow cover characteristics on the Czech-Moravian Highlands," in Climatic Change in the Historical and the Instrumental Periods, pp. 310-314, Masaryk University, Brno, Czech Republic, 1990.

[17] H. Ye, "Quasi-biennial and quasi-decadal variations in snow accumulation over Northern Eurasia and their connections to the Atlantic and Pacific oceans," Journal of Climate, vol. 14, no. 24, pp. 4573-4584, 2001.

[18] R. Brázdil and A. N. Zolotokrylin, "The QBO signal in monthly precipitation fields over Europe," Theoretical and Applied Climatology, vol. 51, no. 1-2, pp. 3-12, 1995.

[19] R. Garnett, N. Nirupama, C. E. Haque, and T. S. Murty, "Correlates of Canadian Prairie summer rainfall: implications for crop yields," Climate Research, vol. 32, pp. 25-33, 2006.

[20] R. W. Malone, D. W. Meek, J. L. Hatfield, M. E. Mann, R. J. Jaquis, and L. Ma, "Quasi-biennial corn yield cycles in Iowa," Agricultural and Forest Meteorology, vol. 149, no. 6-7, pp. 10871094, 2009.

[21] A. N. Zolotokrylin, "Izmenchivost' urozhaynosti pshenitsy na evropeyskoy chasti SSSR v usloviyakh kvazidvukhletney tsiklichnosti atmosfernykh protsessov," Izvestiya Akademii Nauk Seriya Geograficheskaya, no. 2, pp. 59-67, 1985 (Russian).

[22] A. N. Zolotokrylin, S. S. Savina, L. V. Khmelevskaya, and E. I. Klimakova, "Reaktsiya urozhaynosti zernovykh na korotkoperiodicheskuyu izmenchivost' klimata," Izvestiya Akademii Nauk SSSR. Seriya geograficheskya, no. 5, pp. 53-66, 1990.

[23] H. C. S. Thom, "Some methods of climatological analysis," WMO Technical Note 81, Secretariat of the World Meteorological Organization, Geneva, Switzarland, 1966.
[24] T. B. McKee, N. J. Doesken, and J. Kleist, "The relationship of drought frequency and duration of time scales," in Proceedings of the 8th Conference on Applied Climatology, pp. 179186, American Meteorological Society, Anaheim, Calif, USA, January 1993.

[25] A. V. Protserov, "Evaluation of moisture content for spring wheat during the growing season," in Guidelines for Analysis and Evaluation of Agrometeorological Conditions, pp. 49-53, Gidrometeoizdat, Leningrad, Russia, 1957, (Russian).

[26] E. S. Ulanova, Agrometeorological Conditions and Yield of Winter Wheat, Gidrometeoizdat, Leningrad, Russia, 1975, (Russian).

[27] E. Kalnay, M. Kanamitsu, R. Kistler et al., "The NCEP/NCAR 40-year reanalysis project," Bulletin of the American Meteorological Society, vol. 77, no. 3, pp. 437-471, 1996.

[28] M. Y. Bardin and A. B. Polonsky, "North Atlantic Oscillation and synoptic variability in the European-Atlantic region in winter," Izvestiya-Atmospheric and Ocean Physics, vol. 41, no. 2, pp. 127136, 2005.

[29] E. A. Cherenkova and N. K. Kononova, "Dangerous meteorological drought over European Russia in the 20-th century and atmospheric circulation processes relationship," Izvestiya Akademii Nauk Seriya Geograficheskaya, vol. 1, pp. 73-82, 2009 (Russian). 

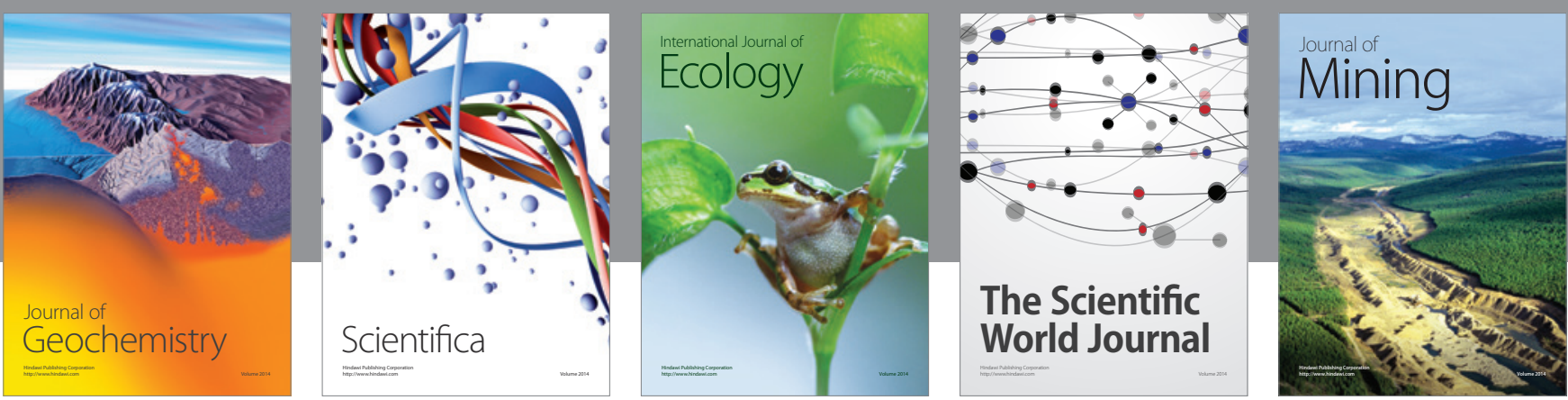

The Scientific World Journal
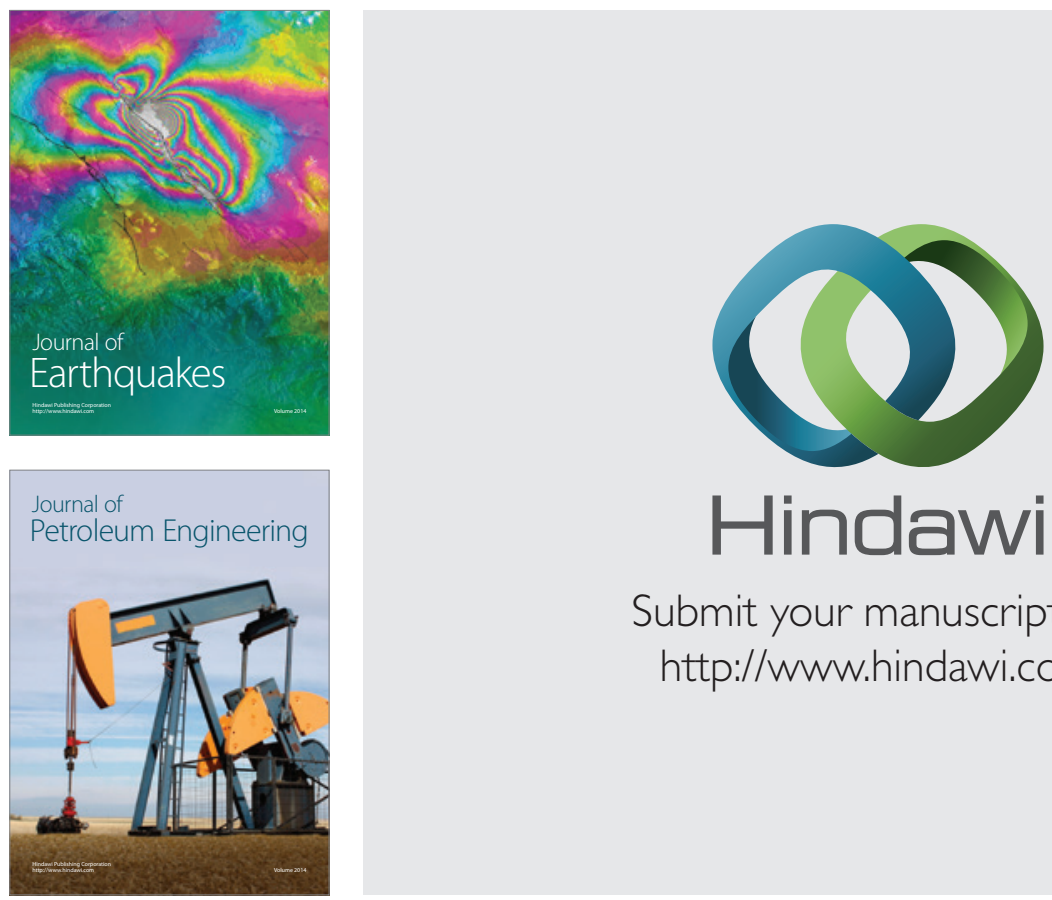

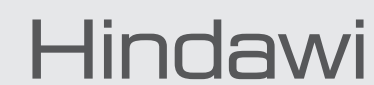

Submit your manuscripts at

http://www.hindawi.com
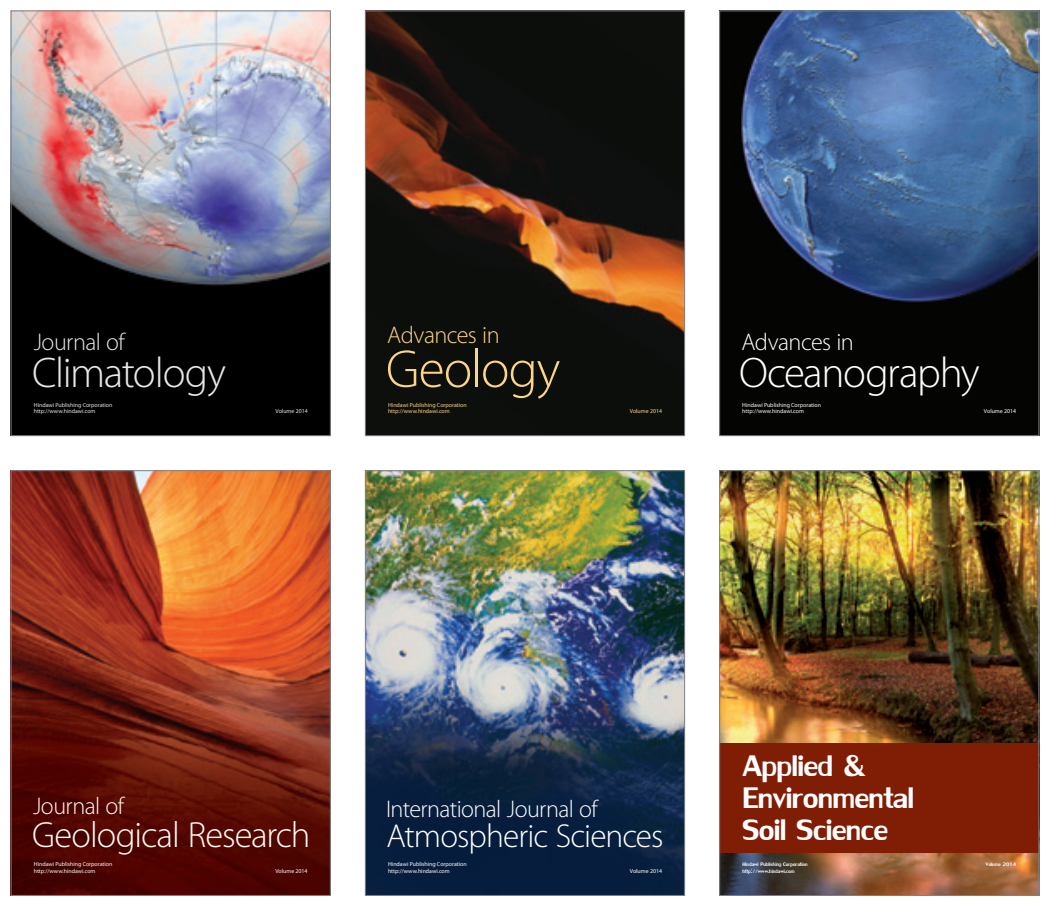
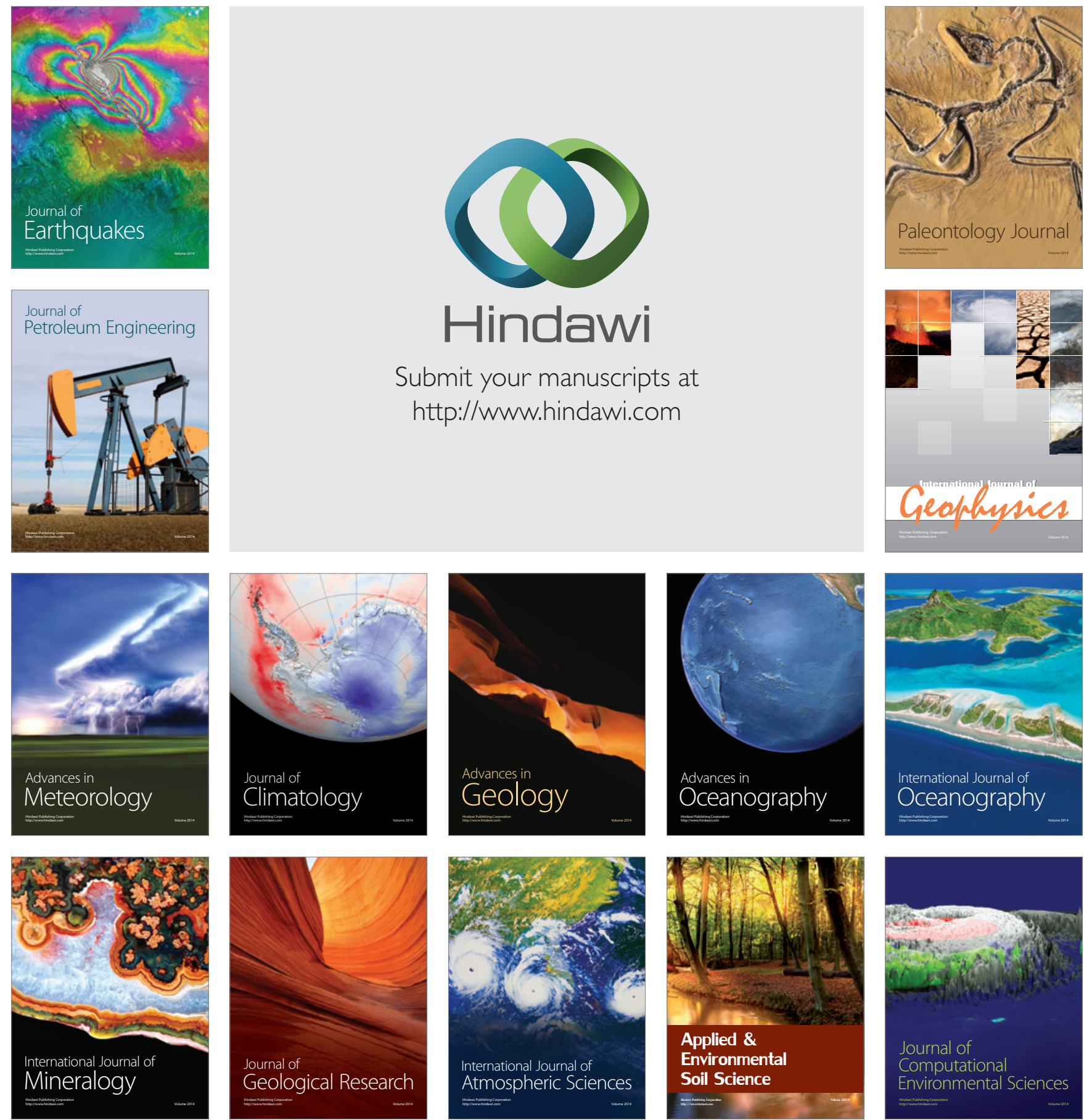